\title{
Speciation of organic matter and heavy metals in urban wastewaters from an emerging country
}

\author{
R. EL KHATIB ${ }^{1,2^{*}}$, B.S. LARTIGES ${ }^{1,3^{*}}$, A. EL SAMRANI ${ }^{2 *}$,

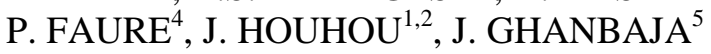

\footnotetext{
${ }^{1}$ Nancy University - LEM-ENSG/INPL-CNRS, Pôle de l'Eau, 15 Avenue du Charmois, BP 40 54501 Vandouvre Cedex, FRANCE

${ }^{2}$ Lebanese university-Faculty of Sciences-Doctoral School-Platform of Research for Environmental Sciences-Campus Hadath, Lebanon

${ }^{3}$ University of Toulouse - GET - 14, Avenue E. Belin, 31400 Toulouse, France

${ }^{4}$ Nancy University - SCMEM-FST/UHP, 7137 boulevard des Aiguillettes, BP 239

54506 Vandoeuvre Cedex, FRANCE
}

(*) To whom correspondence should be addressed

E-mail: bruno.lartiges@get.obs-mip.fr

rime.alkhatib@ensg.inpl-nancy.fr

elsamrani@hotmail.com 


\begin{abstract}
Analytical scanning and transmission electron microscopy, sequential chemical extraction, and pyrolysis-gas chromatography on solvent extractable organic matter, are used to provide both direct and indirect speciation of heavy metals and organic matter in sewage suspended solids and in biofilms taken from an urban sewer in an emerging country. Compared to developed countries where the domestic activities represent the main source of heavy metal pollution in wastewater, the combined sewer system of an emerging country also integrates significant contributions originating from the private drinking water supply system $(\mathrm{Zn}, \mathrm{Cu}$, $\mathrm{Cr}$, and $\mathrm{Ni})$, industrial discharges $(\mathrm{Cu}, \mathrm{Mn})$, and road dust transported by street washing $(\mathrm{Pb})$. The relative importance of those sources changes drastically over time as evidenced by the difference in metal levels recorded between weekday and weekend effluents. Nevertheless, sewer biofilms are found to provide a good averaging of contaminant loads and they can be used as environmental archives. The speciation study reveals the predominance of neoformed minerals such as sulfides and phosphates, and highlights the strong biogeochemical dynamics that takes place within the sewer system. Electron microscope observations of heavy metalbearing phases proved to be necessary to provide a consistent interpretation of chemical extraction results. The molecular characterization of the solvent-extractable organic matter from biofilms reveals the presence of classical fingerprints of domestic activity such as faecal sterols and detergents, but also confirms a major contribution of petroleum byproducts consistent with a traffic-related pollution.
\end{abstract}

Keywords: urban effluent, biofilm, heavy metal, electron microscopy, pyrolysis-gas chromatography-mass spectrometry. 


\section{INTRODUCTION}

The lack of wastewater treatment facilities in emerging countries leads to a substantial release of contaminants in the aquatic environment from urbanized areas (Mara 2004). The environmental impacts of those discharges are quite diverse, from a severe sediment contamination in the vicinity of outfalls, heavy metal accumulation across trophic levels, changes in the assemblage of the phytoplankton community due to nutrient additions from sewage, and on a larger scale, to a significant perturbation of element geocycling (Galloway 1979; Krepakevich and Pospelova 2010; Azzurro et al. 2010).

While previous research has mainly focused on determining the loadings of contaminants from the effluent to the receiving environment and on evaluating the areas affected by the anthropogenic discharges (Galloway 1979; Gromaire et al. 2000; Gasperi et al. 2008; Hwang et al. 2009; Krepakevich and Pospelova 2010), studies clarifying the nature of organic matter in sewage or the speciation of heavy-metal bearing particles in urban wastewater, remain scarce (El Samrani et al. 2004; Houhou et al. 2009b; Mansuy-Huault et al. 2009). Such information is nevertheless a prerequisite for the modeling of contaminant mobility and bioavailability in the receiving watercourses. Improving the existing knowledge about the quality of local effluents, also contributes to a better design of wastewater treatment plants to be built in emerging countries, and on the long term, is necessary to assess any change in environmental policy regarding the urban water cycle.

The main purpose of this study is to investigate the nature of heavy metal-bearing particles and organic matter contained in an urban wastewater from Lebanon which is injected to the Medirerranean Sea. As such effluents are known to be complex and highly variable in composition (Soonthornnanda and Christensen 2008), sampling was conducted during weekdays and weekends, and biofilms in contact with the wastewater were also characterized as potential historical records of contaminant inputs in the sewer system. In addition to chemical analyses that provided the total metal concentrations, both electron microscopy combined with energy dispersive X-ray spectrometry and sequential extration were used to describe the speciation of heavy metal-bearing particles, whereas solvent extractable organic matter was characterized by gas chromatography-mass spectrometry.

\section{EXPERIMENTAL SECTION}

\subsection{Study area}

Sewage samples were taken from Golden Star pumping station (GS) that discharges wastewater collected from the Keserwan urban area (Jounieh, Lebanon) into the sea at 
Tabarja bay (fig. 1). In Lebanon, more than $85 \%$ of the wastewater generated $-249 \mathrm{Mm}^{3}$ of domestic sewage and about $43 \mathrm{Mm}^{3}$ of industrial effluent every year - are directly discharged into the Mediterranean Sea through 53 main outfalls (Karaa et al. 2005; State of Environment (SOER) 2001; El-Fadel et al. 2001; Bdour et al. 2009).

The Kerserwan combined sewer receives both domestic sewage from about 128000 people, and industrial wastewater originating from local jewelry makers, glass carving stores, a leather tannery, a metal plating industry, ceramic tile industries, a vegetable oil industry, and a textile dyeing factory (State of Environment (SOER) 2001; El-Fadel et al. 2001; EM water, 2004). In addition, septic service trucks frequently unload effluent between $11 \mathrm{~h} 00$ and $17 \mathrm{~h} 00$ upstream of GS pumping station, which strongly impacts the sewage characteristics for a few minutes. GS pumping station includes a bar screen at the inlet to protect the pumps from large solids, a $200 \mathrm{~m}^{3}$ collection basin, and it handles wastewater at a $250 \mathrm{~L} / \mathrm{s}$ pumping rate.

\subsection{Sampling and sewage characterization}

Sampling campaigns were conducted under dry-weather conditions in the time period September 2007 to September 2009. Sewage grab samples (20 weekday and 7 weekend samples) were taken from the collection basin and were immediately characterized for temperature, pH (Sentix 41-3), redox potential (Sentix ORP), and conductivity (WTW Multiline F/SET), and turbidity (Hach 2100P). The wastewater characterization also included the measurements of Biological Oxygen Demand (BOD 5 (VELP Scientifica FTC 90I, Italy), Chemical Oxygen Demand (COD) (VELP Scientifica ECO 16, Italy), and a rough determination of Total Suspended Solids (TSS) by drying duplicates of $10 \mathrm{~mL}$ sewage at $105^{\circ} \mathrm{C}$ for $24 \mathrm{~h}$. The sewage was filtered on-site through pre-washed $0.22 \mu \mathrm{m}$ pore size cellulose-acetate filters $\left(\mathrm{Chromafil}^{\circledR}\right.$ CA-20/25) and the filtrates were analyzed for metals (Perkin-Elmer ELAN 6000 ICP-MS), anions (Ionic Chromatography ICS3000 Dionex), and Dissolved Organic Carbon (Leco SC144 DRPC). Biofilm samples were scrapped off the collection basin walls and stored at $4{ }^{\circ} \mathrm{C}$ in glass vials until analysis. The bulk chemical analyses of three biofilm samples collected at different sampling dates and one suspended matter sample were conducted by ICP-MS after $\mathrm{LiBO}_{3}$ fusion and $\mathrm{HNO}_{3}$ dissolution. Samples of drinking water were collected from 5 houses located in the vicinity of GS pumping station.

\subsection{Characterization of heavy metal-bearing phases}

Freeze-dried suspended matter collected on filters and biofilms were examined using both Transmission (Philips CM20) and Scanning (Hitachi 54800) Electron Microscopes equipped 
with Energy-Dispersive X-ray Spectrometers (EDXS). For TEM imaging and microanalysis, the samples were resuspended in ethanol under ultrasonication, and a drop of suspension was evaporated on a carbon-coated copper grid (EuroMEDEX, Mesh 200). A spot size of about 70 $\mathrm{nm}$ was used to record EDX spectra with a counting time of 40 seconds. EDX calibration standards were run to obtain quantitative analyses of major and trace elements with a detection limit of about 100 ppm. SEM-EDXS analyses were performed on samples deposited on double sided carbon adhesive tape, and were carbon coated. Backscattered electron imaging (BEI) was used to locate the particles of interest. In that mode, brightness is related to the average atomic number of materials, and, provided that the heavy element content is sufficient, the heavy metal-bearing mineral phases appear as bright spots that can be easily detected within the organic matrix of samples such as biofilms or sewage suspended matter (Houhou et al. 2009b).

The above direct speciation mode was completed with a sequential extraction analysis of heavy metals inspired by modified Tessier four-step extraction procedure (Tessier et al. 1979). The method, summarized in Table 1, allows to discriminate the forms of heavy metals contained in exchangeable, soluble, reducible, oxidizable, and residual fractions, noted hereafter F1, F2, F3, F4, and F5, respectively. The heavy metal concentrations in each fraction and the total heavy metal load were determined by Atomic Absorption spectrometry (Analytik Jena, Zeenit 700).

\subsection{Characterization of organic matter}

Resin-embedded samples of sewage suspended matter and biofilm were prepared for TEM observation. The samples, first fixed with glutaraldehyde and osmium tetroxide, were passed through stepwise acetone dehydration, before being impregnated in a graded series of epoxy resin monomer in acetone solutions, and finally polymerized in molds at $60^{\circ} \mathrm{C}$ for $24 \mathrm{~h}$ (Lartiges et al. 2001). Sections (100 nm thick) were cut on a Reichert OM U2 ultramicrotome with a diamond knife, stained with lead citrate and uranyl acetate, and placed on copper grids for TEM examination.

The solvent extractable organic matter was separated using a ASE200 DIONEX automated solvent extraction system. The freeze-dried sample (1 g) was first mixed with $15 \mathrm{~g}$ of Fontainebleau sand, copper chips being also added for desulphurization. The organic compounds were then extracted using methylene chloride (MC), and the extract was evaporated to dryness. The residue was dissolved in $4 \mathrm{~mL} \mathrm{MC}$, an aliquot of $15 \mathrm{mg}$ was taken to dryness, and redissolved in $300 \mu \mathrm{L} \mathrm{MC}$. The organic compounds were then separated into 
aliphatic, aromatic, and polar fractions using alumina and silica chromatographic columns. The aliphatic and aromatic fractions were eluted from the alumina column with $3 \mathrm{~mL} \mathrm{MC}$, whereas the residual polar fraction was eluted with 50/50 vol\% methanol/MC. The aliphatic compounds were then separated from the aromatic fraction using the silica column with $3 \times 1$ $\mathrm{mL}$ pentane. Finally, the aromatic fraction was recovered by washing the silica column with $5 \times 500 \mu \mathrm{L}$ of $35 / 65 \mathrm{vol} \% \mathrm{MC} /$ pentane mixture. The polar fraction was purified on the silica column with $50 / 50 \mathrm{vol} \%$ methanol/MC. The three fractions were taken to dryness, the aliphatic and aromatic compounds were redissolved in hexane, whereas the polar fraction was derivatized with $150 \mu \mathrm{L}$ of BSTFA and $250 \mu \mathrm{L}$ of $\mathrm{MC}$ at $60^{\circ} \mathrm{C}$ for $15 \mathrm{~min}$.

Gas Chromatography (GC) was carried out using a Hewlett-Packard G1800A (Agilent Technologies) equipped with a DB 5-MS $60 \mathrm{m*} 0.125 \mathrm{~mm}$ capillary column, linked to a Hewlett-Packard G1034C Mass Spectrometer operating in fullscan mode. The injector was in splitless mode at $300^{\circ} \mathrm{C}$, the $\mathrm{GC}$ oven initial temperature being initially set at $70^{\circ} \mathrm{C}$ for $2 \mathrm{~min}$, followed by a $15^{\circ} \mathrm{C} \min ^{-1}$ ramp to $130^{\circ} \mathrm{C}$, then by a $3^{\circ} \mathrm{C} \min ^{-1}$ ramp to $315^{\circ} \mathrm{C}$, and a final hold for $15 \mathrm{~min}$. Helium was the carrier gas set at a flow rate of $1.4 \mathrm{~mL} / \mathrm{min}$.

\section{RESULTS AND DISCUSSION}

\subsection{Wastewater quality and major inorganic species}

The main characteristics of Golden Star sewage are presented in table 2. In accordance with the Mediterranean climate experienced by the coastal area of Lebanon, the average temperature of GS sewage is rather high, which certainly favors the bacterial activity and may stimulate mineral precipitation such as carbonates within the sewer system (Pantsar-Kallioa et al. 1999; Eriksson et al. 2000). Nevertheless, on the whole, the mean values of parameters measured on GS sewage fall within the ranges classically reported in the literature for wastewaters (Tchobanoglou et al. 2003). During weekdays, the relatively low values noted for conductivity, $\mathrm{BOD}_{5}$ and $\mathrm{COD}$ concentrations, certainly reflect the contribution of industrial wastewaters to the effluent load. The $\mathrm{COD} / \mathrm{BOD}_{5}$ ratio is about 2.3 , thus indicating that GS organic matter is easily biodegradable.

Table 3 lists the soluble concentrations of major inorganic ions in GS sewage and tap water. In Lebanon, the drinking water supply often relies both on municipal supply and private groundwater extraction (Korfali and Jurdi 2007). As the drinking water samples were collected at various houses around the study site, this explains why, in tap water, the standard deviations for measurements of potassium, magnesium, calcium, and to a lesser extent 
chlorine, are rather important. Notable differences can be observed between weekend and weekday effluents. Thus, the phosphate level in weekend wastewaters is much higher than in weekday sewage. However, at the moment, Lebanon has not yet banned orthophosphate in laundry detergents, and the phosphate load can certainly be related to the frequent use of washing machines during the weekend (Almeida et al. 1999; Eriksson et al. 2002; Butler et al. 1995; Comber et al. 1996; Gray et Becker 2002). The amount of sulfate and sodium in the weekend sewage may also be explained in part by the use of washing powder, since those ions are common constituents of traditional detergents (Eriksson et al. 2002). Nevertheless, some $\mathrm{Na}$ and $\mathrm{SO}_{4}$ ions certainly originate from human excreta. Interestingly, tap water represents a principal source of nitrate in GS wastewater. However, as can be observed in the oxygen-depleted weekday wastewater, microbial denitrification may occur in the sewer system and hence, remove all the nitrate content.

In contrast, the concentrations of $\mathrm{Ba}, \mathrm{Ca}$, and $\mathrm{K}$, in both weekday and weekend effluents are almost constant. Tap water is the main source of calcium and barium in GS wastewater. These cations usually exhibit a non-conservative behaviour in the sewer system with frequent precipitations of carbonates and barite (Eriksson et al. 2000; Houhou et al. 2009a). In the present case, the solubility calculations indicate that the weekend effluent is indeed slightly supersaturated with regard to barite, whereas the weekday sewage is close to saturation. Human excreta are generally considered as the main contributor to the potassium load in wastewater (Verbanck et al. 1989; Vinneras and Jönsson 2002). Hence, the constancy of dissolved $\mathrm{K}$ in both weekday and weekend sewages appears rather puzzling, since it would suggest that the dilution of domestic sewage due to industrial discharges is actually negligible. On the contrary, chlorine known to behave most often conservatively (Viers et al. 2001), implies a one-third dilution of domestic wastewater by the industrial discharge, provided that industrial wastewater does not contribute to the chlorine budget.

\subsection{Heavy metal loads in GS sewage}

The dissolved metal concentrations in GS sewage and tap water are given in Table 4. Obviously, the dissolved $\mathrm{Zn}$ found in wastewater essentially originates from tap water. Indeed, even though the municipal drinking water system mainly uses unlined iron and cast iron pipes, the private distribution network is made up of galvanized iron and stainless steel pipes (Korfali and Jurdi 2007). The high level of $\mathrm{Zn}$, but also part of dissolved Ni and the considerably high $\mathrm{Cr}$ concentration with regard to the maximum admissible concentration in drinking water (EU Directive 98/83), can then be related to the corrosion of those pipes 
(Sorme and Lagerkvist 2002; Comber et al. 1996; Kamar 2009; Houhou et al. 2009b). Similarly, the value of dissolved $\mathrm{Al}$ in sewage can be explained by the $\mathrm{Al}$ input from drinking water since an aluminum coagulant is used at Dbayeh treatment facility supplying the study site. On the other hand, the levels of $\mathrm{Cr}$ and $\mathrm{Ni}$ strongly increase in weekend wastewater, which is in accordance with previous reports showing that household sources releasing stainless steel fragments such as washing machines, dish washers, kitchen cookware, and kitchen sinks, are significant contributors for those metals in sewage (Chino et al. 1991; Sorme and Lagerkvist 2002; Comber and Gunn 1996; Houhou et al. 2009b). The contribution of industrial discharges to the soluble metal load in weekday sewage concerns essentially $\mathrm{Cu}$ and $\mathrm{Mn}$. Both metals may be tentatively related to the activity of a metal plating industry located nearby (State of Environment (SOER) 2001).

Table 4 also presents the total metal loads in weekday wastewater, as well as the heavy metal contents found in suspended matter and in three biofilms collected at various times over the period of the study. Obviously, most of the metal load transported in GS wastewater is associated with suspended solids. This may explain why the heavy metal levels found in biofilms are equivalent with those measured for sewage suspended matter, and why they are rather constant over time. Indeed, in those sewer biofilms, the quantity of metal adsorbed from solution should be negligible in comparison with the amount of suspended solids transferred to the wall by shear forces. In that case, the biofilm should provide a continuous and quantitative record of the particle contamination history in the sewer. Such view has been previously put forward by Rocher et al. (2004) for hydrocarbons stored in sewer biofilms. The total heavy-metal levels in weekday wastewater appear rather high in comparison with those typically reported in the literature (Gasperi et al. 2008; Houhou et al. 2009b). High concentrations in $\mathrm{Zn}$ and $\mathrm{Pb}$ are usually attributed to roof runoff (Chebbo et al. 2001). This explanation cannot hold for the study area, the major source of $\mathrm{Zn}$ in GS sewage being probably tap water. On the other hand, the $\mathrm{Pb}$ pollution found in wastewater is certainly linked with the urban road dust sediment that is transferred to the combined sewer by frequent morning street-washing (Gromaire et al. 2000; Barrett et al. 2010). Indeed, in Lebanon, leaded gasoline remains a common grade, and average $\mathrm{Pb}$ concentrations as high as $353 \mu \mathrm{g} / \mathrm{g}$ have been measured in roadside dust along urban streets (Hashisho and El Fadel 2004). Part of Zn and Cd load may also originate from traffic-induced emissions (Legret and Pagotto, 1999; Sorme and Lagerkvist 2002). The total $\mathrm{Cu}$ concentration appears to be significantly higher than usual copper levels reported in the literature for wastewater (Gasperi et al. 2008; Houhou et al. 2009b), the main source of this element in GS sewage likely originating from the 
discharge of metal plating wastes. In a previous paper, Houhou et al. (2010b) reported that very similar concentrations of total $\mathrm{Cu}, \mathrm{Zn}, \mathrm{Cd}, \mathrm{Ni}$, and $\mathrm{Cr}$, are measured nowadays in the sewage of various western cities. Such observation, attributed in part to the globalization of consumer behavior, cannot be extended to countries such as Lebanon where a stringent environmental legislation for industrial discharges has not been implemented yet.

\subsection{Nature of heavy metal-bearing particle}

The dominant crystalline phases revealed by X-ray diffraction in the biofilms were quartz $\left(\mathrm{SiO}_{2}\right)$, bassanite $\left(\mathrm{CaSO}_{4}, 5 \mathrm{H}_{2} \mathrm{O}\right)$, and anatase $\left(\mathrm{TiO}_{2}\right)$. Bassanite is very likely formed during the freeze-drying of samples since the solubility calculations indicate that such a species is not stable in GS sewage. The occurrence of abundant quartz particles in sediments from a separate sewer system has been related to its use as scouring powder in household cleaning (Houhou et al. 2009b), but in the present case (combined sewer), it may also result from sand used for construction work and mobilized by street cleaning. The presence of anatase may be attributed to its use as pigment in a ceramic industry located in the vicinity of Golden Star pumping station.

A direct speciation of heavy metal-bearing particles contained in sewage suspended solids and in sewer biofilms was carried out by combining electron microscopy with EDXS analysis. Barium sulfate and barium sulfate associated with zinc sulfide, iron oxides, metal sulfides, and various alloys, were the phases commonly identified using this approach (fig. 2). The frequent occurrence of barium sulfate (fig. 2a-b) is certainly the result of the supersaturation of GS sewage for barite, although anthropic sources such as car brakes are also likely here (El Samrani et al. 2004). The association between barium sulfate and zinc sulfide has a double origin as indicated by the bimodal histogram of the $\mathrm{Ba} / \mathrm{Zn}$ elemental ratio (inset of fig. 3 ). The first mode - Ba/Zn close to 1 - probably identifies lithopone (Clark 2002; Adams 2004), a white pigment used in some enamels and paints that could originate from the ceramic industry. The second mode $-\mathrm{Ba} / \mathrm{Zn}$ around 4 - could correspond to $\mathrm{ZnS}$ particles directly grown on the barite surface under the influence of sulfate-reducing bacteria (El Samrani et al. 2004). Other metal sulfides such as mackinawite $(\mathrm{FeS})$, pyrite $\left(\mathrm{FeS}_{2}-\right.$ fig. $\left.2 \mathrm{c}\right)$, galena $(\mathrm{PbS})$, covellite $(\mathrm{CuS})$, chalcopyrite $\left(\mathrm{CuFeS}_{2}\right.$ - fig. $\left.\left.2 \mathrm{~d}\right)\right)$, sphalerite $(\mathrm{ZnS})$, and argentite $\left(\mathrm{Ag}_{2} \mathrm{~S}\right)$, were found in equivalent amounts in suspended solids and biofilms. As discussed by several authors (El Samrani et al. 2004; Zhang et al. 2008; Houhou et al. 2009b), those sulfides are formed by the reaction of dissolved metal species with the hydrogen sulfide produced by sulfato-reducing bacteria (Gutierrez et al. 2008; Nielsen et al. 2008). 
The weight of the ceramic industry in the amount of anthropogenic particles discharged in GS sewage is even more obvious when oxide particles are considered: pigments such as lead oxide $(\mathrm{PbO})(10.5 \%)$, bismuth oxide $(5.8 \%)$, chromium oxide $(1.2 \%)$ and lead chromate $\left(\mathrm{PbCrO}_{4}\right)$ (2.3\%) (fig. 2e) (Zheng and Shi 2007; Clark 2002), but also polishing agents such as cerium oxides $(6.9 \%$ ) (fig. 2f), are frequently observed in weekday wastewater and in biofilms. Other identified oxides include bismuth oxychloride (BiOCl) (2.3\%) (fig. 2g) and wustite (FeO) (fig. 2h), that should rather be related to the cosmetic industry.

Besides stainless steel fragments (fig. 2i) that were predominantly found in weekend sewage in accordance with the relative levels of total $\mathrm{Cr}$ and $\mathrm{Ni}$ measured in suspended solids, a variety of metal alloys were observed in GS wastewater. Brasses such as $\mathrm{Cu}-\mathrm{Zn}, \mathrm{Cu}-\mathrm{Zn}-\mathrm{Al}$ (aluminium brass), and $\mathrm{Cu}-\mathrm{Zn}-\mathrm{Sn}$ (white brass), were identified in biofilms and only in weekday sewage. The presence of those brasses may be associated with the activity of the metal plating industry. $\mathrm{Fe}-\mathrm{Cr}$ particles, attributed to fragments of razor blades by Houhou et al. (2009b), were identified in high amounts in weekend wastewater, whereas Fe-Cr alloys bearing minor amounts of $\mathrm{Sn}$ and $\mathrm{Sb}$ were analyzed in weekday sewage. Micron size particles of gold (fig. 2j) - 22 karats ( $\mathrm{Au} \mathrm{91.7 \% ,} \mathrm{Ag} \mathrm{3.2 \% ,} \mathrm{and} \mathrm{Cu} 5.1 \%$ ) and 18 karats ( $\mathrm{Au} \mathrm{75 \% ,9 \%}$ $\mathrm{Ag}$, and $\mathrm{Cu} \mathrm{16 \% )-} \mathrm{were} \mathrm{evidenced} \mathrm{in} \mathrm{weekday} \mathrm{wastewater.} \mathrm{Obviously,} \mathrm{such} \mathrm{particles}$ originate from the jewelry industry (Ingo et al. 1998; Manni et al. 2001). More annecdotally, particles of native bismuth (fig. 2k) and thorium dioxide found in biofilms could be the signature of granite kitchen sinks which are very popular in Lebanon.

A previous investigation of phosphate minerals neoformed in wastewater revealed that a significant amount of $\mathrm{Zn}$ can be entrapped into those minerals (Houhou et al. 2009a). In the present case, such $\mathrm{Zn}$ incorporation within the phosphate phases could not be evidenced with regard to the minimum detection limit of EDXS. On the other hand, lead-bearing phosphate species that might originate from a remobilization in the sewer system of $\mathrm{Pb}$ from roadside dust, frequently occur (fig. 2i). Figure 3 shows the relative abundance between weekdays and weekends of the three main types of metal bearing particles distinguished above. Neoformed mineral species, i.e. particles precipitated as metal sulfides or phosphates, are in equivalent amount in weekday and weekend wastewater, and they largely dominate the other categories of particles. This indicates that the dynamic chemical environment of the sewer system determines drastic changes in the speciation of many metals over a short time scale. Logically, the occurrence of particles originating from domestic uses and industrial processes are more abundant during weekend and weekday, respectively. 


\subsection{Chemical speciation of heavy metals in suspended solids and biofilm}

A major drawback of the direct speciation conducted with electron microscopy is that the total amount of trace element associated with a given species is not known. In addition, some heavy metal-bearing phases may be overlooked because of the relatively low sensitivity of EDXS microanalysis. However, a chemical speciation is not devoid of artifacts either, and incomplete dissolution of the target phase, readsorption of dissolved species, or precipitation of neoformed phases, have been described in the literature (Ostergren et al. 1999; La Force and Fendorf 2000; Houhou et al. 2009a). Figure 4 presents the partitioning of $\mathrm{Zn}, \mathrm{Pb}$, and $\mathrm{Cu}$, between exchangeable (F1), soluble (F2), reducible (F3), oxidizable (F4), and residual fractions (F5). Zn is mainly associated with the soluble and reducible fractions in suspended solids and biofilms, and to a lesser extent with the oxidizable fraction. At first approximation, this speciation seems rather contradictory with the electron microscopy observations since $\mathrm{Zn}$ was only detected as sulfide $(\mathrm{ZnS})$. However, no particular precaution was taken during the storage of freeze-dried samples, and a partial oxidation of those metal sulfides would then significantly increase the amount of $\mathrm{Zn}$ contained in the reducible fraction. Such an evolution of speciation during storage has recently been described for suspended particulate matter in the Seine river by Priadi et al. (2012).

A similar partitioning is observed for $\mathrm{Pb}$ in suspended solids, whereas it is mainly associated with the residual fraction in biofilms. The latter observation is consistent with the abundant occurrence of lead phosphate in that compartment, the very low solubility of this mineral species leading to its extraction with the residual fraction (Ma and Rao 1997). $\mathrm{Cu}$ is mainly distributed between F3, F4, and F5, in suspended solids, and between F4 and F5 in biofilms. Assuming that F3 corresponds to partially oxidized copper sulfide, $\mathrm{Cu}$ would then be originally associated with the organic and/or sulfide fraction identified by SEM as covellite and chalcopyrite, and with the residual fraction that could then correspond to copper brasses. Eventually, the results obtained by chemical extraction can be easily related to the direct speciation carried out by electron microscopy.

\subsection{Nature of organic matter in suspended solids and biofilms}

Typical micrographs of sewage suspended solids and biofilm samples are shown in figure 5 . An intense microbial activity is systematically observed within the suspended material with numerous bacterial aggregates embedded in a matrix of extracellular polymeric substances (fig. 5a), and frequent biodegradation features at the surface of decaying organic fibers (fig. 5b). In contrast, TEM examination of biofilm samples reveals a range of diverse situations 
that can be related to the variation in bacteria abundance in the thickness of the biofilm (Mahfoud et al. 2009). At the biofilm/sewage interface that contains the majority of microbial biomass, ongoing biodegradation characterized by remnants of cell walls (fig. 5c) and partially degraded plastic chunks can be observed (fig. 5d). In contrast, other micrographs completely devoid of active bacteria (fig. 5e-f), might identify deeper zones within the biofilm (Mahfoud et al. 2009). Interestingly, cellulose fibers originating from toilet papers which are frequently observed in biofilms and suspended solids in western countries were not detected. This may be related to the local usage of not flushing down the toilet paper. Such habit can certainly impact the sewer functioning as it was established that about $15 \%$ of sewer solids correspond to toilet paper in UK (Friedler et al. 1996).

The measured values of total organic carbon and volatile matter in biofilm samples were $633 \pm 107 \mathrm{mg} / \mathrm{g}$ and $202 \pm 135 \mathrm{mg} / \mathrm{g}$, respectively, which is of the order of magnitude of organic contents for sewer biofilms reported in the literature (Chebbo et al. 2001). The amount of extractable organic matter was $433 \pm 115 \mathrm{mg} / \mathrm{g}$ with percentages of aliphatic, aromatic, and polar fractions of $38.2 \%, 18.1 \%$, and $15.7 \%$, respectively, the loss during the fractioning process being about $30 \%$.

The GC-MS analysis is dominated by n-alcanes, pentacyclic triterpanes, and an unresolved complex mixture (UCM) (fig. 6a). n-Alkanes are detected with chain length from C12 to C29 (fig. 6c). The value of the Carbon Preference Index (CPI), defined as the odd/even carbon number n-alkanes (Bray and Evans 1961) equal to 1.03, confirms the petrogenic fingerprint (Moilleron et al. 2002; Jeanneau et al. 2006; Jeanneau et al. 2008). Moreover, the distribution of pentacyclic triterpanes (especially hopanes) is dominated by isomers in geological conformation $(17 \alpha, 21 \beta$ and $17 \beta, 21 \alpha)$ whereas a biological conformation $(17 \beta, 21 \beta)$ is not detected (figure 6b). Such distribution is typical of thermally matured organic matter (Peter and Moldowan 1993) related to petroleum or associated byproducts such as road asphalts (Faure et al. 2000), The UCM shape in the chromatogram (fig. 6a) is also similar to those obtained for road asphalts or used vehicule oil (Faure and Landais 2000; Faure et al. 2000; Jeanneau et al. 2008).

The aromatic fraction reveals the presence of substituted polycyclic aromatic hydrocarbons (mainly alkyl-phenanthrenes and alkyl-pyrenes) consistent with petroleum byproducts (Jeanneau et al. 2008). This is in contrast to previous results in the literature which reported the predominance of parent PAH such as phenantrene, pyrene, and fluoranthene in sewage sludges (Rocher et al. 2004; Sanchez-Brunet et al. 2007). Linear alkyl benzene (LAB), 
anionic surfactants from domestic detergents (Eganhouse and Sherblom 2001), are also dominant molecules in the aromatic fraction.

Other classical fingerprints of domestic activity such as coprostanol, a faecal sterol produced from the reduction of cholesterol (Eganhouse and Sherblom 2001; Maldonado et al. 2000), cholesterol, cholestanol, and coprostanone, can be evidenced in the polar fraction. In addition, fatty acids with a 14 to 18 carbon number with an even to odd predominance occur. Such distribution is generally associated with a contribution of bacterial biofilm (Killops and Killops 2005).

\section{CONCLUSION}

The results of the present study indicate that, in an emerging country, the sewer system integrates the pollution from four main sources: besides domestic activities, the private drinking water supply system, industrial discharges, and road dust transported in the sewer by street washing, represent majors contributors to the pollution transported by the urban effluent. The relative importance of those sources changes drastically over time as evidenced by the difference in metal levels recorded between weekday and weekend effluents. In that context, the relatively constant composition of biofilms scrapped off the pipe walls appears to provide a time-average measurement of the contamination. The molecular characterization of the solvent-extractable organic matter from biofilm confirms a major contribution of petroleum byproducts consistent with a traffic-related pollution. The speciation study reveals the predominance of neoformed minerals such as sulfides and phosphates, and highlights the strong biogeochemical dynamics that takes place within the sewer system. Unlike western countries in which any discharge from the industry is strictly regulated, some anthropogenic particulate markers of various activities such as jewellery making or ceramics manufacturing can be easily identified here.

The present study provides a base-line against which any improvement in the management of urban water cycle resulting from a change in environmental policy, can be assessed. These results also account for the nature and the speciation of ancient heavy metal pollution found in river sediments in western countries.

\section{Acknowledgements}

R. AL KHATIB would like to thank the Lebanon National Council for Scientific Research for funding her doctoral studies. This work was supported in part by the France-Lebanon bilateral cooperation (CEDRE 06EF29/L43 grant). RK, AS, and BL are grateful to the staff of Golden 
Star pumping facility for logistical support during field sampling. The authors also wish to thank the SARM staff (CRPG-UPR 80) where chemical analyses were carried out

\section{References}

Almeida, MC., Butler, D., Friedler, E. (1999). At-source domestic wastewater quality. Urban Water, 1, 49-55.

Azzurro, E., Matiddi, M., Fanelli, E., Guidetti, P., La Mesa, G., Scarpato, A., Axiak, V. (2010). Sewage pollution impact on Mediterranean rocky-reef fish assemblages. Marine Environmental Research 69(5), 390-397.

Barrett, J.E.S., Taylor, K.G. Hudson-Edwards, K.A., Charnock, J.M. (2010). Solid-phase speciation of $\mathrm{Pb}$ in urban road dust sediment: a XANES and EXAFS study. Environ. Sci. Technol., 44, 2940-2946.

Bdour, A. N., Hamdi, M., Taraweh, Z. (2009). Perspectives on sustainable wastewater treatment technologies and reuse options in the urban areas of the Mediterranean region. Desalination, 237, 162-174.

Butler, D., Friedler, E., Gatt, K., (1995). Characterizing the quantity and quality of domestic wastewater inflows. Wat.Sci.Tech., 31 (7),13-24.

Chebbo, G., Gromaire, M.C., Aherre, M., Garnaud, S., (2001). Production and transport of urban wet weather pollution in combined sewer systems: the «Marais » experimental urban catchment in Paris. Urban water, 3, 3-15.

Chino, M., Moriyama, K., Saito, H., Mori, T., (1991). The amount of heavy metals derived from domestic sources in Japan. Water, Air, Soil Pollut., 57-58, 829-837.

Clark, R., (2002). Pigment identification by spectroscopic means: an art/science interface. C.R.chimie, 5, 7-20.

Comber, S.D.W., Gunn, A.M., (1996). Heavy metals entering sewage-Treatment works from domestic sources. Wat. Environ. J., 10(2), 137-142.

Eganhouse, R.P., Sherblom, P.M., (2001). Anthropogenic organic contaminants in the effluent of a combined sewer overflow: impact on Boston Harbor. Mar. Environ. Res., 51, 5174.

El Samrani, A.G., Lartiges, B.S., Ghanbaja, J., Yvon, J., Kohler, A., (2004). Trace element carriers in combined sewer during dry and wet weather: an electron microscope investigation. Wat. Res., 38, 2063-2076.

El-Fadel, M., Zeinati, M., El-Jisr, K., Jamali, D., (2001). Industrial-waste management in developing countries: The case of Lebanon. J. Environ. Manage., 61, 281-300.

EMwater (Efficient Management of Wastewater) (2004). European project, final report,. http://www.emwater.org/activities/final_cs_lebanon.pdf.

Eriksson, E., Auffarth, K., Henze, M., Ledin, A., (2002). Characteristics of grey wastewater. Urban Water, 4, 85-104

Faure, P., Landais, P., Schlepp, L., Michels, R., (2000). Evidence for diffuse contamination of river sediments by road asphalt particles. Environ. Sci. Technol., 34, 1174-1181. 
Faure, P., Landais, P., (2000). Contributions organiques naturelles et anthropiques dans les sédiments du lac de Kruth-Wildenstein (Haut-Rhin, France). C.R. Acad. Sci., 330, 39-46.

Friedler, E., Brown, D.M., Butler, D., (1996). A study of WC derived sewer solids. Wat. Sci. Tech., 33(9), 7-24.

Galloway, J.N., (1979). Alteration of trace metal geochemical cycles due to the marine discharge of wastewater. Geoch. Cosmochim. Acta, 43, 207-218.

Gasperi, J., Garnaud, S., Rocher, V., Moilleron, R., (2008). Priority pollutants in wastewater and combined sewer overflow. Sci. Total Environ., 407, 263-272.

Gray, S.R., Becker, N.S.C., (2002). Contaminant flows in urban residential water systems. Urban Water, 4, 331-346.

Gromaire, M.C., Garnaud, S., Ahyerre, M., Chebbo, G., (2000). The quality of street cleaning waters: comparison with dry and wet weather flows in a Parisian combined sewer system. Urban Water, 2, 39-46.

Gutierrez, O., Mohanakrishnan, J., Sharma, K., Meyer, R., Keller, J., Yuan, Z., (2008). Evaluation of oxygen injection as a mean of controlling sulfide production in a sewer system. Wat. Res., 42, 4549-4561.

Hashisho, Z., El-Fadel, M., (2004). Impacts of Traffic-induced Lead emissions on air, soil, and blood lead levels in Beirut. Environ. Monit. Assess., 93(1-3), 185-202.

Houhou, J., Lartiges, B.S., Hofmann, A., Frappier, G., Ghanbaja, J., Temgoua, A., (2009a). Phosphate dynamics in an urban sewer: A case of Nancy, France. Wat. Res., 43, 1088-1100.

Houhou. J., Lartiges, B.S., Montarges-Pelletier, E., Sieliechi, J., Ghanbaja, J., Kohler, A., (2009b) Sources, nature, and fate of heavy metal-bearing particles in the sewer system. Sci. Total Environ., 407, 6052-6062.

Hwang, H-M., Green, P.G., Young, T.M., (2009). Historical trends of trace metals in a sediment core from a contaminated tidal salt marsh in San Francisco Bay. Environ. Geochem. Health, 31, 421-430.

Ingo, G.M., Chiozzini, G., Faccenda, V., Bemporad, E., Riccucci, C., (1998). Thermal and microbial characterizations of $\mathrm{CaSO} 4-\mathrm{SiO} 2$ investment materials for casting jewellery alloys. Thermochim. Acta 1998, 321:175-183.

Jeanneau, L., Faure, P., Montarges-Pelletier, E., Ramelli, M., (2006). Impact of a Highly Contaminated River on a More Important Hydrologic System: Changes in Organic Markers. Sci. Total Environ., 372, 183-192.

Jeanneau, L., Faure, P., Montarges-Pelletier, E., (2008). Quantitative multimolecular marker approach to investigate the spatial variability of the transfer of pollution from the Fensch River to the Moselle River (France). Sci. Total Environ., 389, 503-513.

Jeanneau, L., (2007). Approche moléculaire quantitative appliquée à l'étude du transfert de micropolluants organiques à la confluence entre la Fensch et la Moselle (France). PhD Dissertation, Institut National Polytechnique de Lorraine.

Kamar, G., (2009). Policy Dialogue on Integrated Water Resources Management Planning in the Republic of Lebanon, Domestic and Industrial Water Needs and Management. EUWI.

Karaa, K., Karam, F., Tarabey, N., (2005). Wastewater treatment and reuse in Lebanon: key factors for future agricultural uses. In Hamdy A. (ed.), El Gamal F. (ed.), Lamaddalena N. (ed.), Bogliotti C. (ed.), Guelloubi R. (ed.) Non-conventional water use: WASAMED project 
Bari : CIHEAM-IAMB / EU DG Research, 310 p. (Options Méditerranéennes : Série B. Etudes et Recherches, n. 53). ISBN 2-85352-331-4. 3. WASAMED (WAter SAving in MEDiterranean agriculture) Workshop, 2004/12/07-10, Cairo (Egypt).

Killops, S.D., Killops, V.J., (2005). Introduction to organic geochemistry, 2nd edition. Blackwell, Oxford, 30-70.

Korfali, S., Jurdi, M., (2007). Assessment of domestic water quality: case study, Beirut, Lebanon. Environ. Monit. Assess., 135, 241-251.

Krepakevich, A., Pospelova, V., (2010). Tracing the influence of sewage discharge on coastal bays of southern Vancouver Island (BC, Canada) using sedimentary records of phytoplankton. Cont. Shelf Res., 30, 1924-1940.

La Force, M.J., Fendorf, S., (2000). Solid-phase iron characterization during common selective sequential extractions. Soil. Sci. Soc. Am. J., 64(5), 1608-1615.

Lartiges, B.S., Deneux-Mustin, S., Villemin, G., Mustin, C., Barrès, O., Chamerois, M., Gerard, B., Babut, M., (2001). Composition and structure and size distribution of suspended particules from the rhine river. Water Res., 35(3), 808-816.

Lebanon State of Environment Report (2001), Ministry of Environment, Republic of Lebanon, http://www.moe.gov.lb/Reports/Pages/SOER2001.aspx

Legret, M., Pagotto, C., (1999). Evaluation of pollutant loadings in the runoff waters from a major rural highway. Sci. Total Environ., 235, 143-150.

Ma, L.Q., Rao, G.N., (1997). Effects of phosphate rock on sequential chemical extraction of lead in contaminated soils. J. Environ. Qual., 26(3), 788-794.

Mahfoud, C., El Samrani, A.G., Mouawad, R., Hleihel, W., El Khatib, R., Lartiges, B.S., Ouaini, N., (2009). Disruption of biofilms from sewage pipes under physical and chemical conditioning. J. Environ. Sci., 21, 1-8.

Maldonado, C., Indira Venkatesan, M., Philips, C., Bayona, J., (2000). Distribution of trialkylamines and coprostanol in San Pedro Shelf sediment adjacent to a sewage outfall. Mar. Pollut. Bull., 40(80), 680-687.

Manni, A., Saviano, G., Massacci, P., (2001). Technical note characterization of gold particles in recoverable waste matrix. Miner. Eng., 14(12), 1679-1684.

Mansuy-Huault, L., Regier, A., Faure, P., (2009). Analysing hydrocarbons in sewer to help in PAH source appointment in sewage sludges. Chemosphere, 75, 995-1002.

Mara, D., (2004). Domestic wastewater treatment in developing countries. Earthscan Ed.

Moilleron, R., Gonzalez, A., Chebbo, G., Thévenot, D., (2002). Determination of aliphatic hydrocarbons in urban runoff samples from «Le Marais » experimental catchment in Paris centre. Wat. Res., 36, 1275-1285.

Nielsen, A.H., Stokbro, V.H., Jensen, H., Wium-Andersen, T., Hvite-Jacobsen T., (2008). Influence of pipe material and surfaces on sulfide related odor and corrosion in sewers. Wat. Res. 42, 4206-4214.

Ostergren, J.D., Brown, G.E., Parks, G.A., Tingle, T.N., (1999). Quantitative speciation of lead in selected mine tailings from Leadville. Co. Environ. Sci. Technol., 33, 1627-1636.

Pantsar-Kallioa, M., Mujunenb, S., Hatzimihalisc, G., Koutou, P., Minkkinenb, P., Wilkiee, P., Connor, M., (1999). Multivariate data analysis of key pollutants in sewage samples: a case study. Anal. Chim. Acta, 393, 181-191. 
Peters, K.E., Moldowan, J.M., (1993). The Biomarker Guide. Interpreting molecular fossils in petroleum and ancient sediments. Prentice Hall, Englewood Cliffs, NJ. 363 pages.

Priadi, C., Ayrault, S., Pacini, S., Bonte, P., (2011). Urbanization impact on metals mobility in riverine suspended sediment: Role of metal oxides. Int. J. of Environ. Sci. Technol., 8(1), $1-18$.

Priadi, C., Le Pape, P., Morin, G., Ayrault, S., Maillot, F., Juillot, F., Hochreutener, R., Llorens, I., Testemale, D., Proux, O., Brown, G.E., (2012). X-ray absorption fine structure evidence for amorphous zinc sulfide as a major zinc species in suspended matter from the Seine River downstream of Paris, Ile-de-France, France. Environ. Sci. Technol. 46(7), 37123770 .

Rocher, V., Azimi, S., Moilleron, R., Chebbo, G., (2004). Hydrocarbons and heavy metals in the different sewer deposits in the «Le Marais» catchement (Paris, France): stocks, distribution and origins. Sci. Total Environ., 323, 107-122.

Sanchez-Martin, M.J., Gracia-delgado, M., Lorenzo, L.F., Rodriguez-Cruz, M.S., Arienzo, M., (2007). Heavy metals in sewage sludge amended soils determined by sequential extraction as a function of incubation time of soils. Geoderma, 142, 262-273.

Soonthornnonda, P., Christensen, E.R., (2008). Source apportionment of pollutants and flows of combined sewer wastewater. Wat. Res., 42, 1989-1998.

Sorme, L., Lagerkvist, R., (2002). Sources of heavy metals in urban wastewater in Stockholm. Sci. Total Environ., 298, 131-145.

Tchobanoglous, G., Burton, F.L., Stensel, H.D., (2003). Wastewater Engineering: Treatment and Reuse, 4th Edition. Metcalf \& Eddy, New York.

Tessier, A., Campbell, P.G.C., Bisson, M., (1979). Sequential extraction procedure for the speciation of particulate trace metals. Anal. Chem., 51, 844-851.

Verbanck, M., Vanderborght, J-P., Wollast, R., (1989). Major ion content of urban wastewater: assessment of per capita loading. Res. J. Wat. Pollut. Control Fed. 6(11-12), $1722-1728$.

Viers, J., Dupre, B., Braun, J-J., Freydier, R., Greenberg, S., Ngoupayou, J.N, Nkamdjou, L.S., (2001). Evidence for non-conservative behaviour of chlorine in humid tropical environments. Aquat. Geochem., 7(2), 127-154.

Vinneras, B., Jönsson, H., (2002). The performance and potential of faecal separation and urine diversion to recycle plant nutrients in household wastewater. Bioresource Technol., 84(3), 275-282.

Zhang, L., Schryver, P., Gusseme, B., Muynck, W., Boon, N., Verstrete, W., (2008). Chemical and biological technologies for hydrogen sulfide emission in sewer systems: A review. Wat. Res. 42, 1-12.

Zheng, C., Shi, K., (2007). A review on the use of waste glasses in the production of cement and concrete. Resour. Conserv. Recy. 52, 234-247. 
Table 1: Summary of the sequential extraction procedure used to assess heavy metal fractionation in Golden Star samples (suspended solids and biofilms).

\begin{tabular}{|c|c|c|}
\hline $\begin{array}{l}\text { Extraction } \\
\text { step }\end{array}$ & $\begin{array}{c}\text { Operationally } \\
\text { defined fraction }\end{array}$ & Experimental conditions (for $5 \mathrm{~g}$ of freeze-dried sample) \\
\hline I & $\begin{array}{c}\text { F1 } \\
\text { Exchangeable }\end{array}$ & $\begin{array}{l}40 \mathrm{~mL} 0.5 \mathrm{M} \mathrm{NaNO}-30 \mathrm{~min} \text { of mixing at room temperature - } \\
\text { centrifugation at } 5000 \mathrm{rpm} \text { for } 30 \mathrm{~min}\end{array}$ \\
\hline II & $\begin{array}{c}\text { F2 } \\
\text { Soluble }\end{array}$ & $\begin{array}{l}40 \mathrm{~mL} 0.1 \mathrm{M} \text { EDTA added to the residue from step } 1-30 \mathrm{~min} \text { of } \\
\text { mixing at room temperature - centrifugation at } 5000 \mathrm{rpm} \text { for } 30 \mathrm{~min}\end{array}$ \\
\hline III & $\begin{array}{c}\mathbf{F 3} \\
\text { Reducible }\end{array}$ & $\begin{array}{l}20 \mathrm{~mL} \text { sodium citrate }(79.4 \mathrm{~g} / \mathrm{L}) \text { and } 20 \mathrm{~mL} \mathrm{NaCO}_{3}(9.82 \mathrm{~g} / \mathrm{L}) \text { are } \\
\text { added to the residue from step } 2-30 \text { min of mixing at } 80^{\circ} \mathrm{C} \text {, then } 1 \mathrm{~g} \\
\text { of sodium bi-sulfite is added to the mixture }-30 \text { min of further mixing } \\
\text { at } 80^{\circ} \mathrm{C} \text { - centrifugation at } 5000 \mathrm{rpm} \text { for } 30 \mathrm{~min}\end{array}$ \\
\hline IV & $\begin{array}{c}\mathbf{F 4} \\
\text { oxidizable }\end{array}$ & $\begin{array}{l}20 \mathrm{~mL} \mathrm{H}_{2} \mathrm{O}_{2}(35 \%) \text { and } 8 \mathrm{~mL} 0.02 \mathrm{M} \mathrm{HNO}_{3} \text { are added to residue from } \\
\text { step } 3-4 \text { hours of mixing at } 85^{\circ} \mathrm{C} \text {, then } 12 \mathrm{~mL} \text { of } 3.2 \mathrm{M} \mathrm{CH}_{3} \mathrm{COONH}_{4} \text {, } \\
\text { and } 20 \%(\mathrm{v} / \mathrm{v}) \text { of } 3 \mathrm{M} \mathrm{HNO}_{3} \text { are added to mixture }-30 \text { min of further } \\
\text { mixing at } 85^{\circ} \mathrm{C} \text { - centrifugation at } 5000 \mathrm{rpm} \text { for } 30 \mathrm{~min} \text {. }\end{array}$ \\
\hline $\mathrm{V}$ & $\begin{array}{c}\text { F5 } \\
\text { Residual }\end{array}$ & $\begin{array}{l}40 \mathrm{~mL} \mathrm{HNO}_{3}(65 \%) \text { are added to the residue from step } 4-30 \mathrm{~min} \text { of } \\
\text { mixing at } 20^{\circ} \mathrm{C} \text { followed by centrifugation at } 5000 \mathrm{rpm} \text { for } 30 \mathrm{~min} \text {. }\end{array}$ \\
\hline
\end{tabular}


Table 2: Routine wastewater parameters at Golden Star pumping station during weekdays and weekends. Redox potentials are referred to the Standard Hydrogen Electrode. It should be noted that most weekday samples were collected in september whereas most weekend samples were taken in october at a lower ambient temperature.

\begin{tabular}{|c|c|c|}
\hline & Weekday & Weekend \\
\hline $\mathrm{pH}$ & $7.6 \pm 0.3$ & $7.7 \pm 0.2$ \\
\hline Conductivity $(\mu \mathrm{S} / \mathrm{cm})$ & $1209 \pm 100$ & $1764 \pm 215$ \\
\hline Turbidity (NTU) & $241 \pm 73$ & $280 \pm 47$ \\
\hline Redox potential (mV) & $-62 \pm 53$ & $33 \pm 43$ \\
\hline Dissolved oxygen (ppm) & $0.5 \pm 0.03$ & $0.96 \pm 0.46$ \\
\hline TSS (mg/L) & $1108.6 \pm 153.2$ & ND* \\
\hline $\mathrm{BOD}_{5}(\mathrm{mg} / \mathrm{L})$ & $109.7 \pm 6.8$ & ND* \\
\hline $\mathrm{COD}(\mathrm{mg} / \mathrm{L})$ & $256.9 \pm 55.5$ & ND* \\
\hline Temperature $\left({ }^{\circ} \mathrm{C}\right)$ & $26.4 \pm 0.8$ & $18.1 \pm 4.5$ \\
\hline
\end{tabular}


Table 3: Soluble concentrations of major inorganic ions in GS sewage and tap water.

\begin{tabular}{|c|c|c|c|}
\hline Ion $(\mathbf{m g} / \mathbf{L})$ & $\begin{array}{c}\text { Weekday } \\
\text { sewage }\end{array}$ & $\begin{array}{c}\text { Weekend } \\
\text { sewage }\end{array}$ & Tap water \\
\hline $\mathrm{PO}_{4}{ }^{3-}$ & $1.91 \pm 3.2$ & $17.98 \pm 2.32$ & $\mathrm{BDL}^{*}$ \\
\hline $\mathrm{SO}_{4}{ }^{2-}$ & $43.05 \pm 13.4$ & $80.61 \pm 9.4$ & $11.2 \pm 2.3$ \\
\hline $\mathrm{Cl}^{-}$ & $218.02 \pm 61.7$ & $270.77 \pm 26.46$ & $105 \pm 14.8$ \\
\hline $\mathrm{NO}_{3}^{-}$ & $\mathrm{BDL}^{*}$ & $3.28 \pm 0.53$ & $3.64 \pm 0.93$ \\
\hline $\mathrm{Na}^{+}$ & $114.4 \pm 10.6$ & $191.2 \pm 23.9$ & $5.1 \pm 0.8$ \\
\hline $\mathrm{K}^{+}$ & $21.34 \pm 4.5$ & $21 \pm 2.5$ & $6.4 \pm 8.2$ \\
\hline $\mathrm{Ca}^{2+}$ & $55.87 \pm 5.04$ & $60.5 \pm 1.3$ & $63.2 \pm 24.7$ \\
\hline $\mathrm{Mg}^{2+}$ & $17.98 \pm 0.92$ & $32.9 \pm 2.2$ & $27.6 \pm 20.5$ \\
\hline $\mathrm{Ba}^{2+} \times 10^{-3}$ & $16.64 \pm 0.54$ & $20.1 \pm 1.7$ & $27.6 \pm 8.2$ \\
\hline
\end{tabular}

* Below Detection Limit 
Table 4: Dissolved and total metal concentrations in GS sewage, tap water, biofilms, and total suspended matter. BDL: Below Detection Limit. NA: Not Applicable.

\begin{tabular}{|l|c|c|c|c|c|c|}
\hline Metal & $\begin{array}{c}\text { Tap water } \\
(\boldsymbol{\mu g} / \mathbf{L})\end{array}$ & $\begin{array}{c}\text { Weekend } \\
\text { sewage } \\
(\boldsymbol{\mu g} / \mathbf{L})\end{array}$ & $\begin{array}{c}\text { Weekday } \\
\text { sewage } \\
(\boldsymbol{\mu} / \mathbf{L})\end{array}$ & $\begin{array}{c}\text { Suspended } \\
\text { matter } \\
(\boldsymbol{\mu g} / \mathbf{g})\end{array}$ & $\begin{array}{c}\text { Biofilm } \\
(\boldsymbol{\mu g} / \mathbf{g})\end{array}$ & $\begin{array}{c}\text { Total metal in } \\
\text { weekday } \\
\text { sewage } \\
(\boldsymbol{\mu g} / \mathbf{L})\end{array}$ \\
\hline $\mathbf{A s}$ & & & & 2.03 & 2.67 & \\
\hline $\mathbf{B i}$ & $0.0027 \pm 0.002$ & $0.012 \pm 0.015$ & $0.015 \pm 0.002$ & 4.157 & $3.01 \pm 0.50$ & 4.62 \\
\hline $\mathbf{C d}$ & $0.028 \pm 0.017$ & $0.024 \pm 0.012$ & $0.03 \pm 0.007$ & 0.925 & $0.91 \pm 0.35$ & 1.05 \\
\hline $\mathbf{C o}$ & $0.15 \pm 0.06$ & $0.38 \pm 0.06$ & $0.32 \pm 0.04$ & 1.687 & $1.87 \pm 0.20$ & 2.18 \\
\hline $\mathbf{C r}$ & $3.18 \pm 1.79$ & $17.50 \pm 5.29$ & $6.75 \pm 0.15$ & 25.36 & $55.16 \pm 8.86$ & 34.84 \\
\hline $\mathbf{C u}$ & $3.53 \pm 3.37$ & $5.49 \pm 3.49$ & $31.43 \pm 23.13$ & 126.3 & $173.93 \pm 33.08$ & 171.37 \\
\hline $\mathbf{N i}$ & $3.08 \pm 0.63$ & $6.87 \pm 0.67$ & $5.44 \pm 0.2$ & 30.4 & $21.86 \pm 2.48$ & 39.1 \\
\hline $\mathbf{P b}$ & $0.17 \pm 0.11$ & $0.73 \pm 0.35$ & $0.89 \pm 0.12$ & 130.85 & $103.06 \pm 15.90$ & 145.8 \\
\hline $\mathbf{S n}$ & & & & 20.38 & 118.5 & \\
\hline $\mathbf{Z n}$ & $284.14 \pm 248.67$ & $43.73 \pm 12.69$ & $46.02 \pm 15.22$ & 1180 & $987.67 \pm 328.96$ & 1353.4 \\
\hline $\mathbf{M n}$ & $0.33 \pm 0.34$ & $8.24 \pm 6.09$ & $27.96 \pm 9.33$ & $\mathrm{BDL}$ & $\mathrm{BDL}$ & $\mathrm{NA}$ \\
\hline
\end{tabular}


Table 5: Identification of pentacyclic triterpanes (cf. figure 6).

\begin{tabular}{|c|c|c|}
\hline Symbol & Compound & Carbon number \\
\hline 1 & $18 \mathrm{a}(\mathrm{H})-22,29,30$-trisnorhopane & $(\mathrm{C} 27)$ \\
\hline 2 & $17 \mathrm{a}(\mathrm{H})-22,29,30$-trisnorneohopane & $(\mathrm{C} 27)$ \\
\hline 3 & $17 \mathrm{a}(\mathrm{H}), 21 \mathrm{~b}(\mathrm{H})-30$-norhopane & $(\mathrm{C} 29)$ \\
\hline 4 & $18 \mathrm{a}(\mathrm{H})-30-$-norneohopane & $(\mathrm{C} 29)$ \\
\hline 5 & $17 \mathrm{a}(\mathrm{H}), 21 \mathrm{~b}(\mathrm{H})$-hopane & $(\mathrm{C} 31)$ \\
\hline 6 & $17 \mathrm{~b}(\mathrm{H}), 21 \mathrm{a}(\mathrm{H})-30$ homomoretane & $(\mathrm{C} 31)$ \\
\hline 7 & $22 \mathrm{~S}-17 \mathrm{a}(\mathrm{H}), 21 \mathrm{~b}(\mathrm{H})-30$ homohopane & $(\mathrm{C} 31)$ \\
\hline 8 & $22 \mathrm{R}-17 \mathrm{a}(\mathrm{H}), 21 \mathrm{~b}(\mathrm{H})-30$ homohopane & $(\mathrm{C} 32)$ \\
\hline 9 & $22 \mathrm{~S}-17 \mathrm{a}(\mathrm{H}), 21 \mathrm{~b}(\mathrm{H})-30$ bishomohopane & $(\mathrm{C} 32)$ \\
\hline 10 & $22 \mathrm{R}-17 \mathrm{a}(\mathrm{H}), 21 \mathrm{~b}(\mathrm{H})-30$ bishomohopane & $(\mathrm{C} 33)$ \\
\hline 11 & $22 \mathrm{~S}-17 \mathrm{a}(\mathrm{H}), 21 \mathrm{~b}(\mathrm{H})-30$ trishomohopane & $(\mathrm{C} 33)$ \\
\hline 12 & $22 \mathrm{R}-17 \mathrm{a}(\mathrm{H}), 21 \mathrm{~b}(\mathrm{H})-30$ trishomohopane & $(\mathrm{C} 34)$ \\
\hline 13 & $22 \mathrm{~S}-17 \mathrm{a}(\mathrm{H}), 21 \mathrm{~b}(\mathrm{H})$-tetrakishomohopane & $(\mathrm{C} 34)$ \\
\hline 14 & $22 \mathrm{R}-17 \mathrm{a}(\mathrm{H}), 21 \mathrm{~b}(\mathrm{H})$-tetrakishomohopane & $(\mathrm{C} 35)$ \\
\hline 15 & $22 \mathrm{~S}-17 \mathrm{a}(\mathrm{H}), 21 \mathrm{~b}(\mathrm{H})-p e n t a k i s h o m o h o p a n e$ & $(\mathrm{C} 35)$ \\
\hline 16 & $22 \mathrm{R}-17 \mathrm{a}(\mathrm{H}), 21 \mathrm{~b}(\mathrm{H})-p e n t a k i s h o m o h o p a n e$ & \\
\hline
\end{tabular}




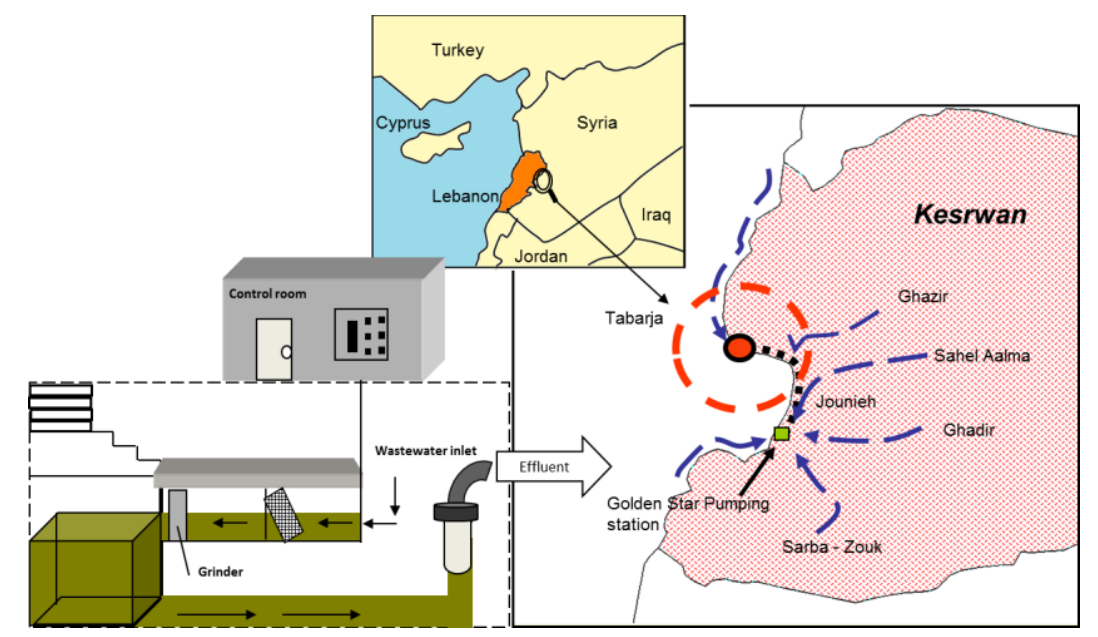

Figure 1: Location of study area and schematic of Golden Star pumping station 


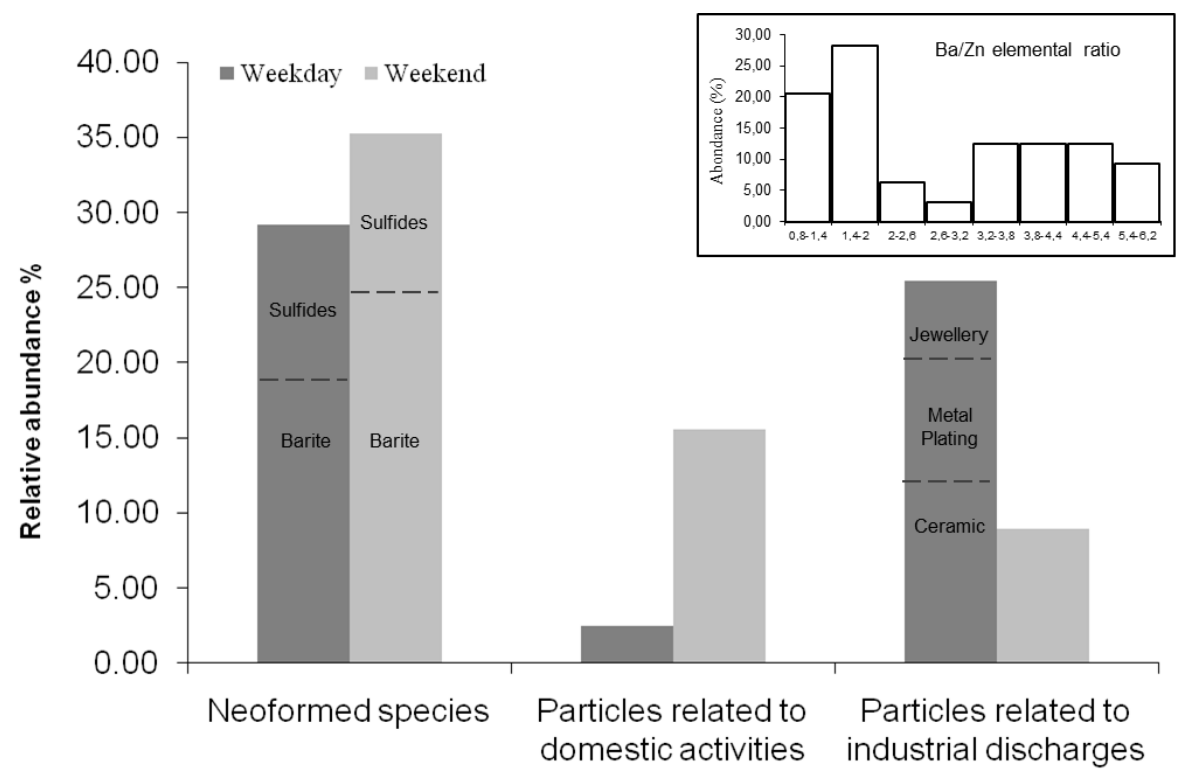

Figure 3: Relative abundance of heavy metal-bearing particles detected by backscattered electron imaging from (i) domestic activities, (ii) industrial wastes, and (iii) the sewer system. The inset shows the histogram of $\mathrm{Ba} / \mathrm{Zn}$ elemental ratios in barite/sphalerite mixed particles. 

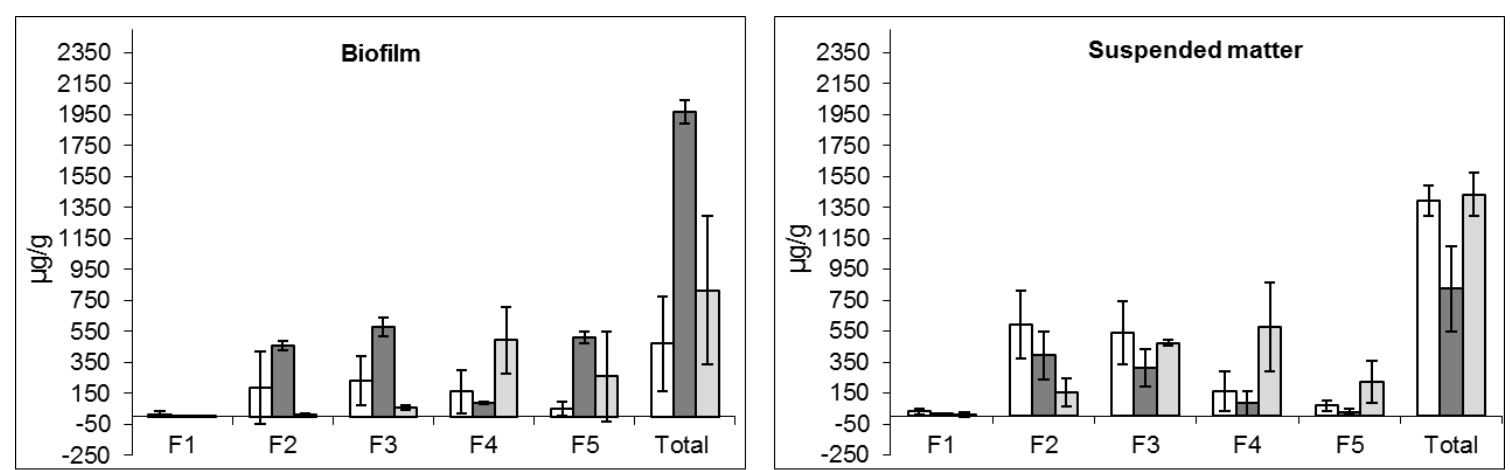

$\square$ Zinc $\square$ Lead $^{\star *} 10 \quad \square$ Cupper*10

Figure 4: Partitioning of $\mathrm{Zn}, \mathrm{Pb}$, and $\mathrm{Cu}$, between exchangeable (F1), soluble (F2), reducible (F3), oxidizable (F4), and residual fractions (F5), in sewage suspended solids and biofilm samples. 

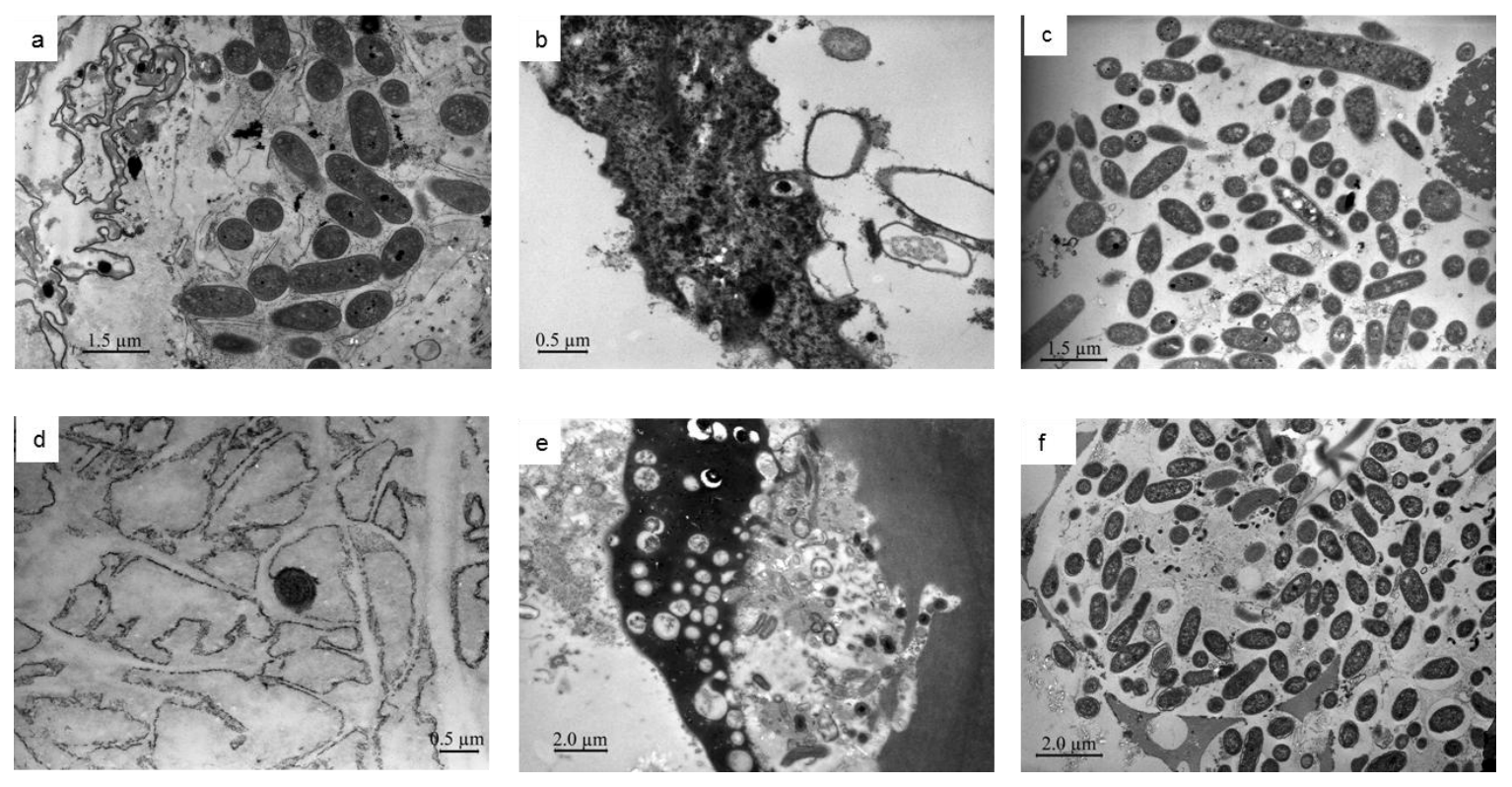

Figure 5: Electron micrographs of stained ultrathin sections of suspended solids (a-b) and sewer biofilms (c-f). 


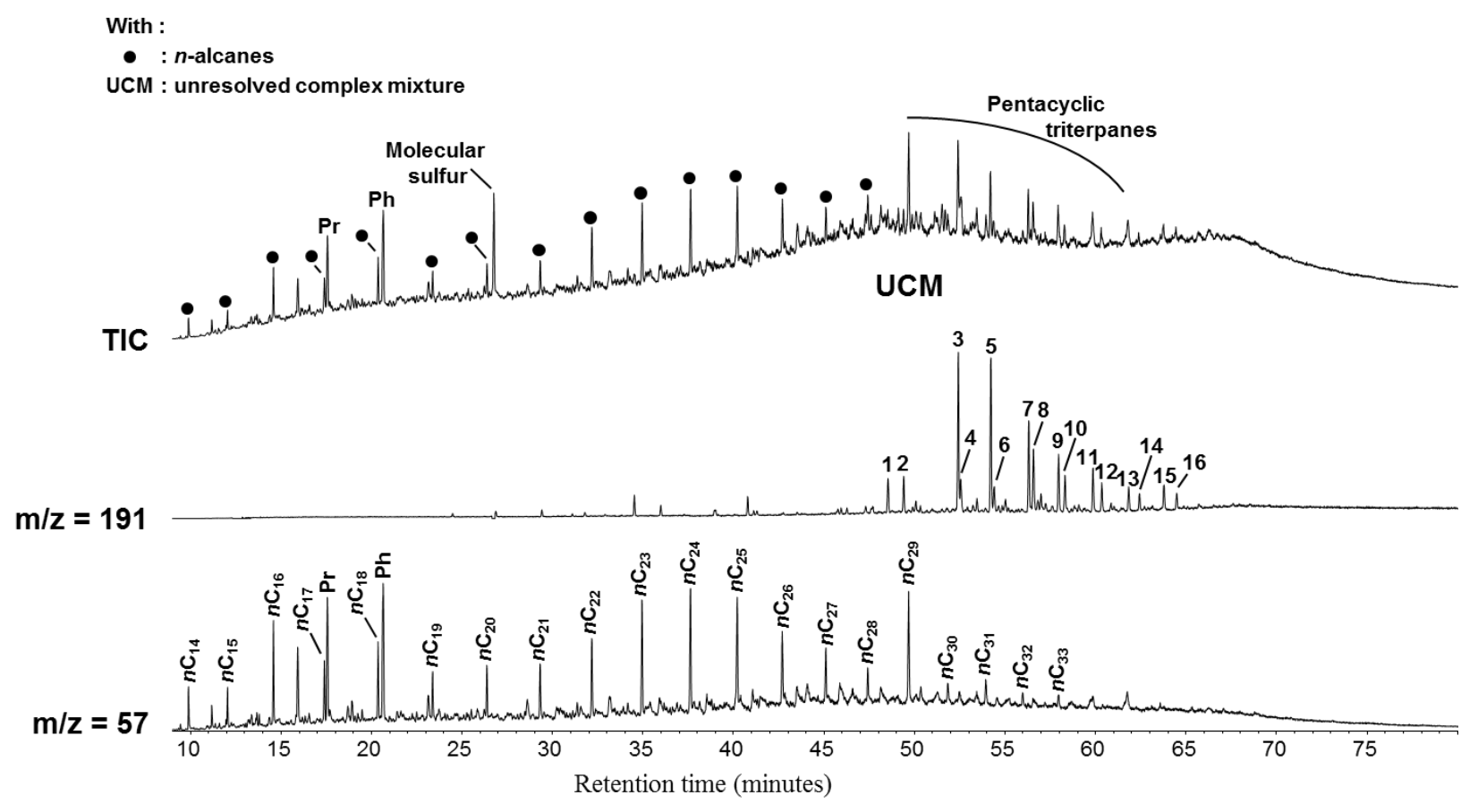

Figure 6: Aliphatic hydrocarbons chromatogram from the biofilm obtained with GC-MS analysis: (a) Total ion curent (TIC), (b) $\mathrm{m} / \mathrm{z}=191$ (pentacyclic triterpanes ) and (c) $\mathrm{m} / \mathrm{z}=57$ (n-alcanes). See table 5 for pentacyclic triterpanes identification (UCM). 